\title{
The Escherichia coli Serogroup 01 and 02 Lipopolysaccharides Are Encoded by Multiple O-antigen Gene Clusters
}

\section{OPEN ACCESS}

Edited by:

Nora Lía Padola,

National University of Central Buenos

Aires, Argentina

Reviewed by:

Charles Martin Dozois,

Institut National de la Recherche

Scientifique, Canada

Roxane Piazza

Instituto Butantan, Brazil

*Correspondence:

Sabine Delannoy

sabine.delannoy@anses.fr

${ }^{\dagger}$ Present Address:

Aubin Fleiss,

Laboratory of Computational and Quantitative Biology, Centre National de la Recherche Scientifique, Institut de Biologie Paris-Seine, Sorbonne

Universités, UPMC, Paris, France

Received: 21 November 2016

Accepted: 23 January 2017

Published: 07 February 2017

Citation:

Delannoy S, Beutin L,

Mariani-Kurkdjian P, Fleiss A, Bonacorsi S and Fach P (2017) The Escherichia coli Serogroup $\mathrm{O} 1$ and $\mathrm{O} 2$ Lipopolysaccharides Are Encoded by Multiple O-antigen Gene Clusters.

Front. Cell. Infect. Microbiol. 7:30. doi: 10.3389/fcimb.2017.00030

\begin{abstract}
Sabine Delannoy ${ }^{1 *}$, Lothar Beutin ${ }^{2,3}$, Patricia Mariani-Kurkdjian ${ }^{4,5,6}$, Aubin Fleiss ${ }^{1+}$, Stéphane Bonacorsi ${ }^{4,5,6}$ and Patrick Fach ${ }^{1}$

${ }^{1}$ IdentyPath Platform, Food Safety Laboratory, Anses, Université Paris-Est, Maisons-Alfort, France, ${ }^{2}$ National Reference Laboratory for Escherichia coli, Federal Institute for Risk Assessment (BfR), Berlin, Germany, ${ }^{3}$ Department of Biology, Chemistry, Pharmacy, Institute for Biology - Microbiology, Freie Universität Berlin, Berlin, Germany, ${ }^{4}$ CNR Associé Escherichia coli, Service de Microbiologie, Hôpital Robert-Debré, Paris, France, ${ }^{5}$ IAME, UMR 1137, INSERM, Paris, France, ${ }^{6}$ IAME, UMR 1137, University Paris Diderot, Sorbonne Paris Cité, Paris, France
\end{abstract}

Escherichia coli strains belonging to serogroups $\mathrm{O} 1$ and $\mathrm{O} 2$ are frequently associated with human infections, especially extra-intestinal infections such as bloodstream infections or urinary tract infections. These strains can be associated with a large array of flagellar antigens. Because of their frequency and clinical importance, a reliable detection of $E$. coli $\mathrm{O} 1$ and $\mathrm{O} 2$ strains and also the frequently associated $\mathrm{K} 1$ capsule is important for diagnosis and source attribution of $E$. coli infections in humans and animals. By sequencing the $\mathrm{O}$-antigen clusters of various $\mathrm{O} 1$ and $\mathrm{O} 2$ strains we showed that the serogroups $\mathrm{O} 1$ and $\mathrm{O} 2$ are encoded by different sets of $\mathrm{O}$-antigen encoding genes and identified potentially new O-groups. We developed qPCR-assays to detect the various $\mathrm{O} 1$ and $\mathrm{O} 2$ variants and the $\mathrm{K} 1$-encoding gene. These qPCR assays proved to be $100 \%$ sensitive and $100 \%$ specific and could be valuable tools for the investigations of zoonotic and food-borne infection of humans with $\mathrm{O} 1$ and $\mathrm{O} 2$ extra-intestinal (ExPEC) or Shiga toxin-producing $E$. coli (STEC) strains.

Keywords: E. coli, extraintestinal E. coli, ExPEC, Shiga toxin-producing E. coli, STEC, serotyping, O-antigen gene cluster, O-AGC

\section{INTRODUCTION}

Strains of the E. coli species are currently divided into 183 O-groups (lipopolysaccharide) and $53 \mathrm{H}$-types (flagellar antigen) (Joensen et al., 2015). For many decades serotyping of O- and $\mathrm{H}$ antigens and in some cases capsular (K-antigens) was the only way to classify E. coli which shared similarities in their fermentation reactions, hosts, virulence markers, and their pathogenicity to humans or animals (Orskov and Orskov, 1984, 1992; Edwards and Ewing, 1986). Most of the genes responsible for the biosynthesis of the $\mathrm{O}$-antigen are located in a single cluster, the $\mathrm{O}$-antigen gene cluster or O-AGC (Reeves et al., 1996; Iguchi et al., 2015a; DebRoy et al., 2016). The size and gene content of the O-AGC vary between serogroups, and two genes, wzx (O-antigen flippase) and $w z y$ (O-antigen polymerase) or wzm (O-antigen $\mathrm{ABC}$ transporter permease gene) and wzt (ABC transporter ATP-binding gene), appear highly specific for each serogroup. These can serve as targets for molecular determination of the serogroup by PCR, qPCR or nucleotide sequencing (Iguchi et al., 2015b; Joensen et al., 2015; Fratamico et al., 2016). The conventional serotype identification, 
based on the serological agglutination of the O-antigens and flagellar $\mathrm{H}$-antigens, is difficult, time consuming and expensive. In addition, many samples remain untypeable by agglutination. Indeed, cross-reactions, the existence of "O rough" strains that have lost their ability to express the $\mathrm{O}$ antigen, and non-motile strains that do not express a flagellar antigen, all hamper the efficiency of the method. Molecular serotyping, targeting genes involved in surface antigen synthesis, appears to be a rapid, specific and cheaper alternative to conventional serotyping.

Escherichia coli strains belonging to serogroups $\mathrm{O} 1$ and $\mathrm{O} 2$ were among the first $20 \mathrm{O}$-serogroups defined when the serotyping scheme was introduced by Kauffmann in 1944 (Orskov and Orskov, 1984). The prototype strains for the E. coli $\mathrm{O} 1$ and $\mathrm{O} 2$ serogroups were from human extra-intestinal infections (Orskov and Orskov, 1984). Escherichia coli O1 and $\mathrm{O} 2$ strains were since found to be associated with disease in humans and animals and also heterogeneous for their hosts, phenotypical traits and the disease they cause in humans and animals. Certain E. coli $\mathrm{O} 1$ and $\mathrm{O} 2$ strains such as $\mathrm{O} 1: \mathrm{K} 1: \mathrm{H} 7$ or $\mathrm{O} 2: \mathrm{K} 1: \mathrm{H} 4, \mathrm{O} 2: \mathrm{K} 1: \mathrm{H} 5, \mathrm{O} 2: \mathrm{K} 1: \mathrm{H} 6$, and $\mathrm{O} 2: \mathrm{K} 1: \mathrm{H} 7$ were identified as causative agents of urinary tract infection, septicaemia, and neonatal meningitis in humans and animals (Orskov, 1978; Achtman et al., 1986; Olesen et al., 1995). Both serogroups account for the majority of strains causing bacteraemia and sepsis in human patients (Orskov and Orskov, 1992; Olesen et al., 1995).

Escherichia coli O1:K1:H7, O2:K1:H4, O2:K1:H5, and $\mathrm{O} 2: \mathrm{K} 1: \mathrm{H} 7$ strains belong to a clonal group (sequence type 95) frequently associated with extra-intestinal diseases in humans and poultry (Dziva and Stevens, 2008; Riley, 2014). These extraintestinal pathogenic E. coli (ExPEC) constitute an emerging public health problem (Johnson et al., 2012a), in particular if they carry plasmids encoding resistance to antimicrobial agents. Meanwhile, the avian pathogenic Escherichia coli (APEC) strains, associated with colibacillosis, a serious illness in poultry worldwide, are the cause of significant economic losses in poultry farms. Poultry strains share some ExPEC virulence traits with human $\mathrm{O} 1: \mathrm{K} 1: \mathrm{H} 7$ or $\mathrm{O} 2: \mathrm{K} 1: \mathrm{H} 7$ isolates and with other ExPEC strains frequently isolated from human patients (Johnson et al., 2006, 2007, 2012b; Dziva and Stevens, 2008; Houdouin et al., 2008; Mora et al., 2009; Peigne et al., 2009; Nandanwar et al., 2014). Escherichia coli O1:H6 strains form another group of ExPEC that were isolated from extra-intestinal infections of dogs, cats and horses (Ewers et al., 2014; Guo et al., 2015).

The human gut microbiota constitutes an important reservoir of E. coli $\mathrm{O} 1: \mathrm{K} 1: \mathrm{H} 1, \mathrm{O} 1: \mathrm{K} 1: \mathrm{H} 7$ and $\mathrm{O} 2: \mathrm{K} 1: \mathrm{H} 4$ and these strains can thus serve as source of extra-intestinal infections (Damborg et al., 2009; Moreno et al., 2009). A possible route of human contamination is through the food supply with an initial colonization of the intestinal tract before onset of an extra-intestinal infection (Manges and Johnson, 2015). Indeed, apart from poultry, many of these ExPEC strains sharing virulence markers with human isolates were isolated from a variety of sources, including animals, food, and the environment (Jakobsen et al., 2010; Singer, 2015). O2 strains such as O2:H6 or $\mathrm{O} 2: \mathrm{H} 42$, are frequently isolated from cattle (Diarra et al., 2009). Escherichia coli O2:H7 similar to isolates causing human infections were also isolated from food (Vincent et al., 2010).
Some Escherichia coli $\mathrm{O} 1$ and $\mathrm{O} 2$ strains producing Shiga toxins (STEC) such as $\mathrm{O} 1: \mathrm{H} 20, \mathrm{O} 1: \mathrm{H} 7, \mathrm{O} 1: \mathrm{H} 2$, and $\mathrm{O} 1: \mathrm{H} 1$ were sporadically isolated from feces of human patients with diarrhea and STEC O2:K1:H7 have caused sporadic cases of HUS in humans (Kobayashi et al., 1993; Beutin et al., 2004; Blanco et al., 2004; Chen et al., 2014). Cattle most likely serves as a reservoir for these strains as STEC O1:H20 and other STEC O1 strains were isolated from bovine meat products and cattle feces (Hussein and Bollinger, 2005; Mekata et al., 2014) while STEC O2:H27 and other STEC O2 have been recovered from feces of cattle, pigs and wild ruminants (Sánchez et al., 2009; Scott et al., 2009; Hutchinson et al., 2011). Interestingly, poultry, pigs and sheep can also harbor enteropathogenic E. coli (EPEC) O2 strains such as O2:H40, O2:H49, or O2:H8 (Fröhlicher et al., 2008; Alonso et al., 2016).

By analyzing different types of $\mathrm{O} 1$ strains, five different serological factors (O1a-O1e) were described (Moll et al., 1986) and three different polysaccharide structures (O1A, O1B, and $\mathrm{O} 1 \mathrm{C}$ ) were characterized which differ slightly in their composition (Gupta et al., 1992). The O1A type corresponded to E. coli $\mathrm{O} 1: \mathrm{K} 1: \mathrm{H} 7$ strains from human patients. The closely related $\mathrm{O} 1 \mathrm{~B}$ and $\mathrm{O} 1 \mathrm{C}$ types were associated with other types of E. coli O1 strains (Achtman et al., 1983; Moll et al., 1986; Gupta et al., 1992). These differences in the LPS structures suggest that serogroup $\mathrm{O} 1$ strains show alterations in their O-antigen encoding genes. Moreover, serogroup O1 was reported to show multiple cross-reactions with other $\mathrm{O}$-serogroups such as $\mathrm{O} 2$, O10, O14, O50, O53, O64, O70, O107, O115, O117, O148, O149, and O154 (Orskov and Orskov, 1984; Edwards and Ewing, 1986). The $\mathrm{O} 2$ antisera can also give cross-reactions with serogroups $\mathrm{O} 1$, O50, O53, O74, and O117 (Edwards and Ewing, 1986).

In this work, we investigated ExPEC, EPEC, and STEC strains of serogroup $\mathrm{O} 1$ and $\mathrm{O} 2$ for their $\mathrm{O}$-antigen encoding genes to explore the nature of different antigens described for $\mathrm{O} 1$ and to explain the cross-reactivity between $\mathrm{O} 1, \mathrm{O} 2$, and other E. coli O-groups. As the nucleotide sequences of $\mathrm{O}$-antigen encoding genes O1-O186 are now available (Iguchi et al., 2015a; DebRoy et al., 2016) we developed a qPCR-based detection procedure to investigate $\mathrm{O} 1$ and $\mathrm{O} 2$ strains of different $\mathrm{H}$-types and from various sources. By sequencing the O-AGC of nonreacting strains, we showed that the serogroups $\mathrm{O} 1$ and $\mathrm{O} 2$ are encoded by different sets of $\mathrm{O}$-antigen encoding genes and identified potentially new serotypes. The capsular antigen K1 contributes to the survival of ExPEC strains in the blood stream and is frequently associated with strains causing septicaemia and meningitis. We developed an additional qPCR assay for the specific detection of the capsular antigen $\mathrm{K} 1$ often associated with the clinically highly important $\mathrm{O} 1$ and $\mathrm{O} 2$ and other ExPEC strains.

\section{MATERIALS AND METHODS}

\section{Bacteria}

Escherichia coli strains used in this study were derived from the collections of the National Reference Laboratory for E. coli (NRL E. coli) at the Federal Institute for Risk Assessment (BfR) in Berlin, Germany, the associated French National Reference 
Center for E. coli at the pediatric Hospital Robert-Debré in Paris (France), and from the French Agency for Food, Environmental and Occupational Health and Safety (Anses) in Maisons-Alfort, France.

Most of the strains studied here belong to previously described collections (Wullenweber et al., 1993; Beutin et al., 2004, 2007, 2016; Bidet et al., 2007; Bugarel et al., 2010; Martin and Beutin, 2011). E. coli strains used to test for the specificity of the qPCR assays included in particular the E. coli reference strains belonging to serogroups O1-O186 and H-types H1-H56. E. coli strains carrying the capsular antigen K1 (Orskov and Orskov, 1984; Wullenweber et al., 1993; Bettelheim et al., 2003) were used as reference strains for the $n e u B$ gene specific real-time PCR described in Table 1.

Two STEC O1 strains, CB13533 (O1:H33) and CB14293 (O1:H20), the E. coli $\mathrm{O} 1: \mathrm{H} 12$ strain $\mathrm{CB} 11070$, the O1 reference strain A47 (O1:HNT), the O50 reference strain U18-41 and two EPEC O2 strains CB11127 (O2:H49) and CB15123 (O2:H40) were investigated for the gene sequences of their $\mathrm{O}$-antigen locus (Table 2).

All strains were grown overnight at $37^{\circ} \mathrm{C}$ in Luria broth, and DNA was extracted according to the manufacturer's instructions using InstaGene matrix (BioRad laboratories, Marnes-LaCoquette, France).

\section{Serotyping of E. coli Strains and Detection of Capsular Antigen K1}

Serotyping of $\mathrm{O}$ (lipopolysaccharide) and $\mathrm{H}$ (flagellar) antigens of the strains received at the $\mathrm{BfR}$ was performed with $\mathrm{O}$-specific and $\mathrm{H}$-specific rabbit antisera prepared according to standard methods (Orskov and Orskov, 1984). The O1 and O2 serogroups reference strains U5-41 (O1:K1:H7) and U9-41 (O2:K1:H4) (Orskov and Orskov, 1984) were used for preparation of E. coli $\mathrm{O} 1$ and $\mathrm{O} 2$ antisera following previously published protocols (Orskov and Orskov, 1984; Edwards and Ewing, 1986). Twofold dilutions of $\mathrm{O}$-antiserum in a range 1:50-1:12,800 were used for testing boiled cultures of bacteria for agglutination reactions. Agglutination reactions \pm one titer step as obtained with the positive control strains U5-41 and U9-41 (both end point titer $1: 12,800$ ) were interpreted as positive for serogroup $\mathrm{O} 1$ or $\mathrm{O} 2$ respectively following published serotyping methods (Orskov and Orskov, 1984; Edwards and Ewing, 1986). Strains carrying the $\mathrm{K} 1$ capsule were detected using $\mathrm{K} 1$ specific bacteriophages as previously described (Wullenweber et al., 1993).

Clinical strains isolated at the Robert Debré hospital were either serotyped by agglutination as described above or serogrouped using a multiplex PCR assay (Clermont et al., 2007). The $\mathrm{K} 1$ antigen was detected using the Wellcogen ${ }^{\mathrm{TM}}$ Bacterial Antigen Rapid Latex Agglutination Test according to the manufacturer's instructions.

\section{PCR Detection and Mapping of E. coli O-antigen Genes}

Nucleotide sequence data obtained from the previously published sequence of the lipopolysaccharide $\mathrm{O} 1$ and $\mathrm{O} 2$ antigens ( $\mathrm{Li}$ et al., 2010) and capsular K1 antigen (Lu et al., 2011) encoding genes
TABLE 1 | Primers and probes for the real-time PCR assays.

\begin{tabular}{|c|c|}
\hline Target gene & $\begin{array}{l}\text { Forward primer, reverse primer, and probe } \\
\text { sequences }\left(5^{\prime}-3^{\prime}\right)\end{array}$ \\
\hline \multirow[t]{3}{*}{ wzyO1A } & CCTITGTATITCTITTGGCTAGTG \\
\hline & CGAATATITTATCCGATGGCTITAG \\
\hline & [6FAM]- AGTCCCGGTCATTGCTTATCGAACTGC-[BHQ1] \\
\hline \multirow[t]{3}{*}{ wzxO1non-A } & AATCATTTGATGTCGGCATGTC \\
\hline & GATIITATACTTACATGGTGGATCGTATC \\
\hline & [6FAM] -TCAGCTATACGCACTGGGCGTCCC-[BHQ1] \\
\hline \multirow[t]{3}{*}{ wzxO2 } & GCCAAGTGCAAAGTTTAATCACAAT \\
\hline & CTTGCCAATTTCCGCAGTATAT \\
\hline & [6FAM]- CCTCTGCACCTGTAAGCACTGGCCTT-[BHQ1] \\
\hline \multirow[t]{3}{*}{ wzXO2-2 (CB11127) } & TCCGTTATATTTGATGGCATTGA \\
\hline & СССТGTТАСАТTССАСССТТСТ \\
\hline & [6FAM]-CAGCGCATTAGTTITCCACTTGCCTTG-[BHQ1] \\
\hline \multirow[t]{3}{*}{ wzxO2-3 (CB15123) } & CCACCACGGTGCACATTTAC \\
\hline & GGACAGGTACAAAGCCTAATGAATATT \\
\hline & [6FAM]-TTCCCTTACCTCCATCCCAATTTCTGC-[BHQ1] \\
\hline \multirow[t]{3}{*}{ neuBK1 } & TCAATAGAACCTGATGAACTGAAACAT \\
\hline & TCTGATCATTCTAGCGGGTITTATG \\
\hline & [6FAM] -TTATTCCATAAGGCACCGCCGCAA - [BHQ1] \\
\hline
\end{tabular}

were used for designing TaqMan ${ }^{\circledR}$ qPCR probes for specific detection of $E$. coli $\mathrm{O} 1-, \mathrm{O} 2-$, and $\mathrm{K} 1$-antigen encoding strains. As some of the investigated $\mathrm{O} 1$ and $\mathrm{O} 2$ strains did not react with the wzyO1A and wzxO2 qPCR assays, the nucleotide sequence of the $\mathrm{O}$-antigen encoding genes of four qPCR-negative $\mathrm{O} 1$ strains (A47, CB11070, CB13533, and CB14293) and two qPCRnegative $\mathrm{O} 2$ strains (CB11127 and CB15123) were determined (see below). A qPCR for the variant $w z x$ gene present in $\mathrm{O} 1$ strains CB13533 and CB14293 was developed and used for further typing of the collection of $E$. coli O1 strains. In a similar way, two qPCRs for the variant $w z x$ genes of CB11127 and $\mathrm{CB} 15123$ were developed and used for molecular typing of E. coli O2 strains (Table 1). Real-time qPCR probes and primers used in this work were designed with the software Primer Express V3.0 (Applied Biosystems) and are described in Table 1.

Real-time PCR assays were performed with an ABI7500 instrument (Applied Biosystems, Foster City, CA, USA) in 25$\mu l$ reaction volumes, a Light Cycler 1536 (Roche Diagnostics, Meylan, France) in 1.5- $\mu$ l reaction volumes or a BioMark (Fluidigm, South San Fransisco, CA, USA) in nanofluidic format according to the recommendations of the suppliers. Primers and TaqMan probes were used at $300 \mathrm{nM}$ final concentrations. The following two-steps thermal profile was applied to all instruments: enzyme activation at $95^{\circ} \mathrm{C}$ for $1-$ $10 \mathrm{~min}$ (as recommended depending on the enzyme used), followed by 40 cycles of denaturation at $95^{\circ} \mathrm{C}$ and annealing at $60^{\circ} \mathrm{C}$. 
TABLE 2 | Properties of the E. coli strains used for sequencing of the O-AGC.

\begin{tabular}{|c|c|c|c|c|c|c|c|}
\hline Strain & Source & Year isolated or reference & Serotype (as defined by agglutination) ${ }^{\star}$ & stx1 & stx2 & eae & Accession number \\
\hline CB11070 & Pig feces & 2007 & O1:H12 & - & - & - & KY115223 \\
\hline CB13533 & Bovine feces & 2011 & O1:H33 & + & - & - & KY115224 \\
\hline CB14293 & veal & 2012 & O1:H2O & + & - & - & KY115225 \\
\hline A47 & reference strain, pig feces & Moll et al., 1986 & O1:[H21] & - & - & - & KY115226 \\
\hline U18-41 & Human urine & 1944 & O50:H4 & - & - & - & KY115227 \\
\hline CB11127 & pig & Fröhlicher et al., 2008 & $\mathrm{O} 2: \mathrm{H} 49$ & - & - & + & KY115228 \\
\hline CB15123 & Chicken meat & 2013 & $\mathrm{O} 2: \mathrm{H} 40$ & - & - & + & KY115229 \\
\hline
\end{tabular}

*Serotypes between brackets were determined with a qPCR-based assay.

\section{Nucleotide Sequencing}

Genomic DNA of strains CB11070, CB13533, CB14293, A47, CB11127, CB15123, and of the O50 reference strain U1841 was extracted from an overnight culture in tryptic soy broth (TSB) medium using the DNeasy blood and tissue kit (Qiagen). The O-antigen cluster of the strains was amplified by long range PCR between the galF and gnd genes, using the Expand Long Range PCR system (Roche) and either the 1523/1524 primers (A47, CB14293, CB13533, CB11127), 412/482 primers (CB15123), or 412/482b primers (CB11070) as described previously (Coimbra et al., 2000; Guo et al., 2004; Perelle et al., 2005). The amplicons were purified using the Charge Switch kit (Invitrogen) and used to prepare libraries with the Nextera XT kit (Illumina) according to the recommendations of the manufacturers. Paired-end short-read sequencing was performed using an Illumina MiSeq instrument (Illumina), according to the manufacturer's instruction. The raw reads were trimmed (minimum length, $35 \mathrm{bp}$; quality score, 0.03) and assembled in CLC Genomics Workbench 7.5.1 by de novo assembly (minimum contig length, $1000 \mathrm{bp}$ ), producing a single contig for each sample. The sequences were annotated using PROKKA (Seemann, 2014) on a Galaxy platform. Unannotated ORFs were further manually curated and analyzed by functional domain analysis using InterPro (Mitchell et al., 2015) and Blastp.

The annotated $\mathrm{O}$-antigen cluster sequences of these strains were deposited in DDBJ/ENA/GenBank under the accession numbers listed in Table 2.

\section{RESULTS}

\section{Analysis of the O-antigen Encoding Genes in E. coli 01 Strains}

A qPCR was developed for the E. coli wzyO1 gene derived from the sequence of the E. coli O1 strain G1632 (U5-41) (Li et al., 2010; GenBank Accession GU299791; Table 1). This PCR was tested on an initial panel of 36 E. coli O1 strains and reacted only with 17 of these (Table 3, see below). The $\mathrm{O} 1$ antigen encoding genes of four non-reacting strains, A47 (O1:H-/[H21]), CB11070 (O1:H12), CB13533 (O1:H33), and CB14293 (O1:H20), were analyzed by nucleotide sequencing.

The O-antigen gene clusters (O-AGC) of strains CB11070, $\mathrm{CB} 13533$, and CB14293 are approximately $10 \mathrm{~kb}$ in length; they all contain 10 ORFs between the galF and gnd genes which all have the same transcriptional direction from galF to gnd (Figure 1, Supplementary Table S1). The overall structure of their O-AGC is similar to that of G1632 with the same genes in the same order (Figure 1). The nucleotide sequence of the $w z x$ and $w z y$ genes of the 3 strains are closely related (99.8$100 \%$ identity; Figure 2). All the other genes from the cluster are similarly related with an overall similarity between the three clusters of $82.5-94.1 \%$ (Supplementary Data S2). All sequences, including $w z x$ and $w z y$, are however distantly related to those of the O1 reference strain G1632 (41-55\% identity). Besides the rmlBDAC genes, which are fairly common genes among various serogroups (Iguchi et al., 2015a; DebRoy et al., 2016), the other ORFs, including the $w z x$ and $w z y$ gene sequences, do not have any significant similarity in the non-redundant nucleotide database of Genbank (Supplementary Table S3).

The O-AGC of strain A47 is different from the other strains (Figure 1). It contains 12 ORFS between galF and gnd in the same transcriptional order from galF to gnd (Supplementary Table S1). It is approximately $16 \mathrm{~kb}$ in length and has an overall structure different from G1632 reference sequence. The $5^{\prime}$-end of the cluster is similar to the other $\mathrm{O} 1$ strains, containing the $r m l B D A C$ gene cluster followed by the $w z x$ gene, the $m n a A$ gene (encoding a UDP-N-acetylglucosamine 2-epimerase) and a glycosyl transferase. However, the second half of the cluster harbors a different set of glycosyl transferase genes. The nucleotide sequence of the $w z x$ gene of strain A47 is somewhat related to that of strains CB11070, CB13533, and CB14293 as they share $89 \%$ identity (89.1-89.2\%). As expected, it is distantly related to that of G1632 (54.4\% identity) and no significant similarity was found in the nucleotide database of Genbank (Supplementary Table S3). Similarly, the mnaA gene and glycosyl transferase (PROKKA_00007) following $w z x$ do not reveal any significant similarity in the nucleotide database of Genbank (Supplementary Table S1). The nucleotide sequence of the wzy gene however is very different from that of G1632 ( $44.7 \%$ identity) and to those of the 3 other strains (48\% identity). A blastn search indicates that it is $89 \%$ identical to the $w z y$ gene of $\mathrm{O} 10: \mathrm{K} 5: \mathrm{H} 4$ strain Bi8337-41. Interestingly, a blast analysis of the glycosyl transferase genes surrounding $w z y$ (PROKKA_00006, PROKKA_00004, and PROKKA_00003) shows 90-94\% identity to the O10 strain Bi8337-41 O-AGC (Supplementary Table S3). The last ORF of A47 O-AGC 
TABLE 3 | Investigation of E. coli 01 strains by qPCR with 01 and K1 specific assays.

\begin{tabular}{|c|c|c|c|c|c|c|c|}
\hline Serotype $^{a}$ & Source, origin & Reference/year isolated & Stx & Nos of strains & wzyo1A & $w z x_{01 \text { non-A }}$ & neuBK1 \\
\hline $\mathrm{O} 1: \mathrm{K} 1: \mathrm{H} 7$ & See footnote b & See footnote $b$ & - & 11 & + & - & + \\
\hline O1:H31 & Sheep feces, Norway & Döpfer et al., 2010 & - & 1 & + & - & - \\
\hline O1:[H34] & Cattle feces, Germany & This work, 2008 & - & 1 & + & - & - \\
\hline $\mathrm{O} 1: \mathrm{H} 42$ & Human feces, France & This work, 2009 & - & 1 & + & - & - \\
\hline O1:H6 & Human feces, France, Switzerland & Geser et al., 2012 & - & 2 & + & - & - \\
\hline $\mathrm{O} 1: \mathrm{H} 10$ & Cattle feces, Germany & This work, 2011 & Stx1 & 1 & + & - & - \\
\hline $\mathrm{O} 1: \mathrm{H} 12$ & Pig feces, Germany & This work, 2007 & - & 1 & - & + & - \\
\hline $\mathrm{O} 1: \mathrm{H} 20$ & See footnote c & See footnote c & Stx1 & 15 & - & + & - \\
\hline O1:H33 & Cattle feces, Germany & This work, 2011 & Stx1 & 1 & - & + & - \\
\hline O1:H19 & Pig feces, Germany & Beutin et al., 1993 & - & 1 & - & + & - \\
\hline O1:NM & A47, O1non-A reference strain, pig feces & Moll et al., 1986; Gupta et al., 1992 & - & 1 & - & + & - \\
\hline
\end{tabular}

a Serotypes between brackets were determined by flic gene sequencing.

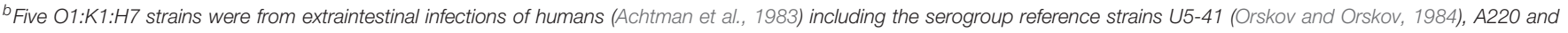
A25 (Achtman et al., 1983; Moll et al., 1986). Four 01:K1:H7 strains were from diseased poultry and two from feces of healthy infants (Bettelheim et al., 2003).

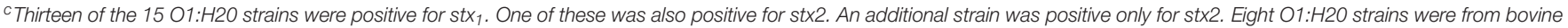

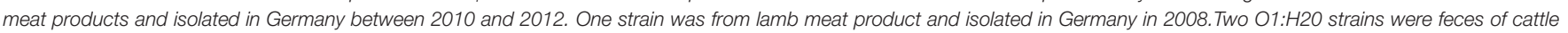

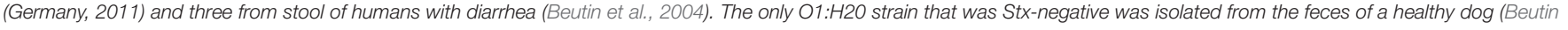
et al., 1993).

(PROKKA_00002) shows 91\% identity to the wekS gene of O2 strain G1674 O-AGC (Supplementary Table S3).

\section{Analysis of the O-antigen Encoding Genes in E. coli 02 Strains}

We confirmed the published sequence of O50 reference strain $\mathrm{U} 18-41$ by de novo sequencing. The O-AGC for serogroups $\mathrm{O} 2$ and $\mathrm{O} 50$ are over 99\% identical (Iguchi et al., 2015a; DebRoy et al., 2016). An alignment of O2 and O50 O-AGC sequences show that they differ by less than 10 SNPs with only 2 SNPs apparently differentiating $\mathrm{O} 2$ and $\mathrm{O} 50$ (not due to interindividual variations or sequencing errors) which could thus be considered as a single serogroup (Supplementary Table S4).

A qPCR was developed for the E. coli O2/O50wzx gene derived from the sequence of the E. coli O2 strain G1674 (Li et al., 2010; GenBank Accession GU299792.1; Table 1). This PCR was tested on an initial panel of 23 E. coli O2 strains and reacted only with 13 of these (Table 4 , see below). The $\mathrm{O} 2$ antigen encoding genes of two non-reacting strains, CB11127 (O2:H49) and CB15123 (O2:H40), were analyzed by nucleotide sequencing.

The O-AGC of both strains are different from each other and from the reference sequence G1674 (Figure 1). The O-AGC of strains CB11127 and CB15123 are approximately $15 \mathrm{~kb}$ in length and contain 14 and 15 ORFs between galF and gnd in the same transcriptional order from galF to gnd, respectively (Supplementary Table S1). The nucleotide sequence of the $w z x$ and $w z y$ genes of both strains have only $37.7-60.2 \%$ identity to each other and to the $\mathrm{O} 2$ and $\mathrm{O} 50$ reference strains (Figure 3). While $\mathrm{O} 2$ reference sequence G1674, O50 reference sequence $\mathrm{U} 18-41$ and $\mathrm{CB} 15123$ possess the $r m l B D A C$ genes, CB11127 is missing the $r m l D$ and $r m l C$ genes. Both $\mathrm{CB} 11127$ and CB15123 also harbor the extra $\operatorname{man} B$ and $\operatorname{man} C$ genes of the GDP-mannose pathway and different sets of putative glycosyl transferases. Transposases are inserted between the manC and manB genes of CB11127 without any apparent gene disruption. Blast analyses of CB11127 ORFs indicate that most of them (including $w z x$ and $w z y$ ) are significantly similar to a single sequence in Genbank nucleotide collection corresponding to strain FHI98 (strain of unknown serotype isolated from human feces in 2011) (Supplementary Table S3). Besides the rmlBDA genes which are found in the O-AGC of multiple isolates of various serogroups, blastn analyses of CB15123 do not find any significantly similar sequences for most of its ORFs (including $w z x$ and $w z y$ ) in Genbank nucleotide collection (Supplementary Table S3).

\section{Development and Evaluation of qPCR Assays for Identification of $E$. coli 01,02 , and K1 Strains}

Major differences between O1A and O1non-A strains were found in their corresponding $w z x$ and $w z y$ genes which are the principal targets used for molecular O-typing of E. coli (Iguchi et al., 2015a; Joensen et al., 2015). Certain sequence alterations in these two genes could be attributed to $E$. coli O1A and O1non-A strains, respectively, and qPCR assays for their specific detection were developed (Table 1). When tested with an initial panel of 36 well characterized O1 strains, the qPCR assay derived from the sequence of the ExPEC O1A strain U5-41 (wzyO1A) detected all O1 strains belonging to H-types H6, H7, H10, H31, H34, and H42. The qPCR assay derived from the STEC O1:H20 strain CB13533 (wzxO1non-A) detected all $\mathrm{O} 1$ strains belonging to $\mathrm{H}$-types $\mathrm{H} 12, \mathrm{H} 19, \mathrm{H} 20$, and $\mathrm{H} 33$ (Table 3). We have tested the qPCRs developed for detection of O1A type and O1 non-A strains for reaction with the reference strains for serogroups O1-O186. None of the reference strains belonging to other O-groups than $\mathrm{O} 1$ reacted with the wzyO1A or with the wzxO1non-A qPCR assays. Additionally, they were 

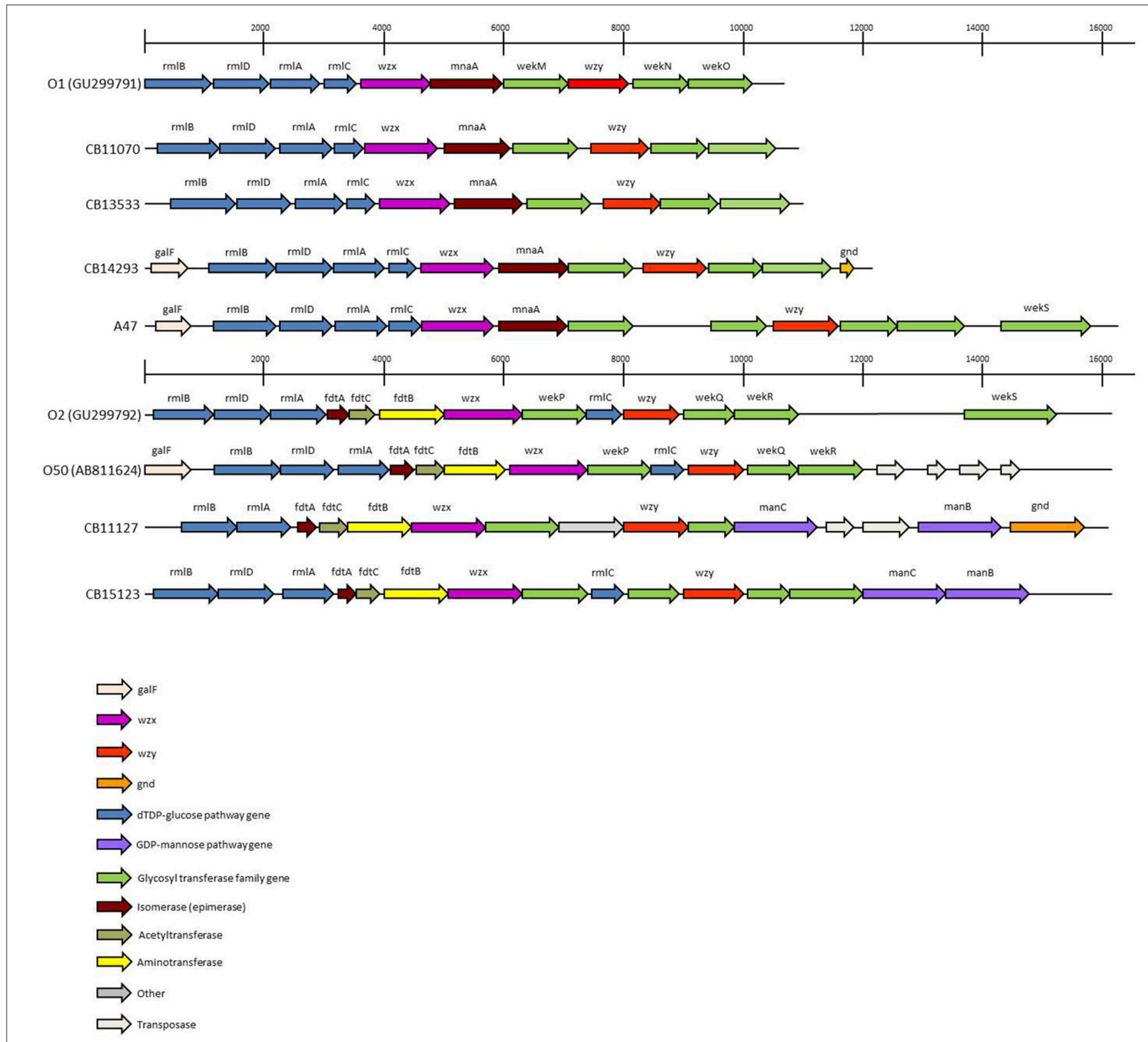

FIGURE 1 | The O-Antigen gene clusters of 01, 02 and 050 strains and variants thereof. The accession numbers of sequences obtained from public databases are indicated. The open arrows represent the location and orientation of the putative genes identified.

tested against a panel of 153 strains (Table 5), including 130 strains of serogroups other than $\mathrm{O} 1$, belonging to 43 different serogroups. None of the strains belonging to O-groups other than $\mathrm{O} 1$ reacted with the wzyO1A or with the wzxO1nonA qPCR assays. The wzyO1A qPCR assay reacted only with strains of serotype O1:K1:H7 $(n=17)$, while the wzxO1nonA qPCR assay reacted only with strains of serotype O1:H12 $(n=1), \mathrm{O} 1: \mathrm{H} 20(n=3), \mathrm{O} 1: \mathrm{H} 21(n=1)$, and O1:H33 $(n=1)$. Thus, the qPCR detection method was found to be far more specific for identification of $E$. coli $\mathrm{O} 1$ strains than conventional O-serotyping. Moreover, the qPCR assays used here discerned clearly between E. coli O1A and O1non-A type strains, respectively.
The divergence between the $w z x$ sequences of strains U941 (O2:K1:H4), CB11127 (O2:H49), and CB15123 (O2:H40) allowed us to design three qPCR assays, targeting the $\mathrm{O} 2 / \mathrm{O} 50$ and two O2-like serogroups respectively (Table 1). When tested with an initial panel of 23 well characterized $\mathrm{O} 2$ strains, the qPCR assay derived from the sequence of the ExPEC O2 strain U9-41 (wzxO2) detected all $\mathrm{O} 2$ strains belonging to $\mathrm{H}$-types $\mathrm{H} 1, \mathrm{H} 4, \mathrm{H} 6$, $\mathrm{H} 7$, and $\mathrm{H} 25$. The qPCR assay derived from the O2:H49 strain $\mathrm{CB} 11127$ (wzxO2-2) detected the $\mathrm{O} 2$ strains belonging to $\mathrm{H}$-type $\mathrm{H} 49, \mathrm{H} 34$, and $\mathrm{H} 29$. The qPCR assay derived from the O2:H40 strain $\mathrm{CB} 15123$ (wzxO2-3) detected all O2:H40 strains and the $\mathrm{O} 2: \mathrm{H} 8$ strain (Table 4). The wzxO2, wzxO2-2, and wzxO2-3 qPCRs did not react with any of the O1-O186 reference strains 


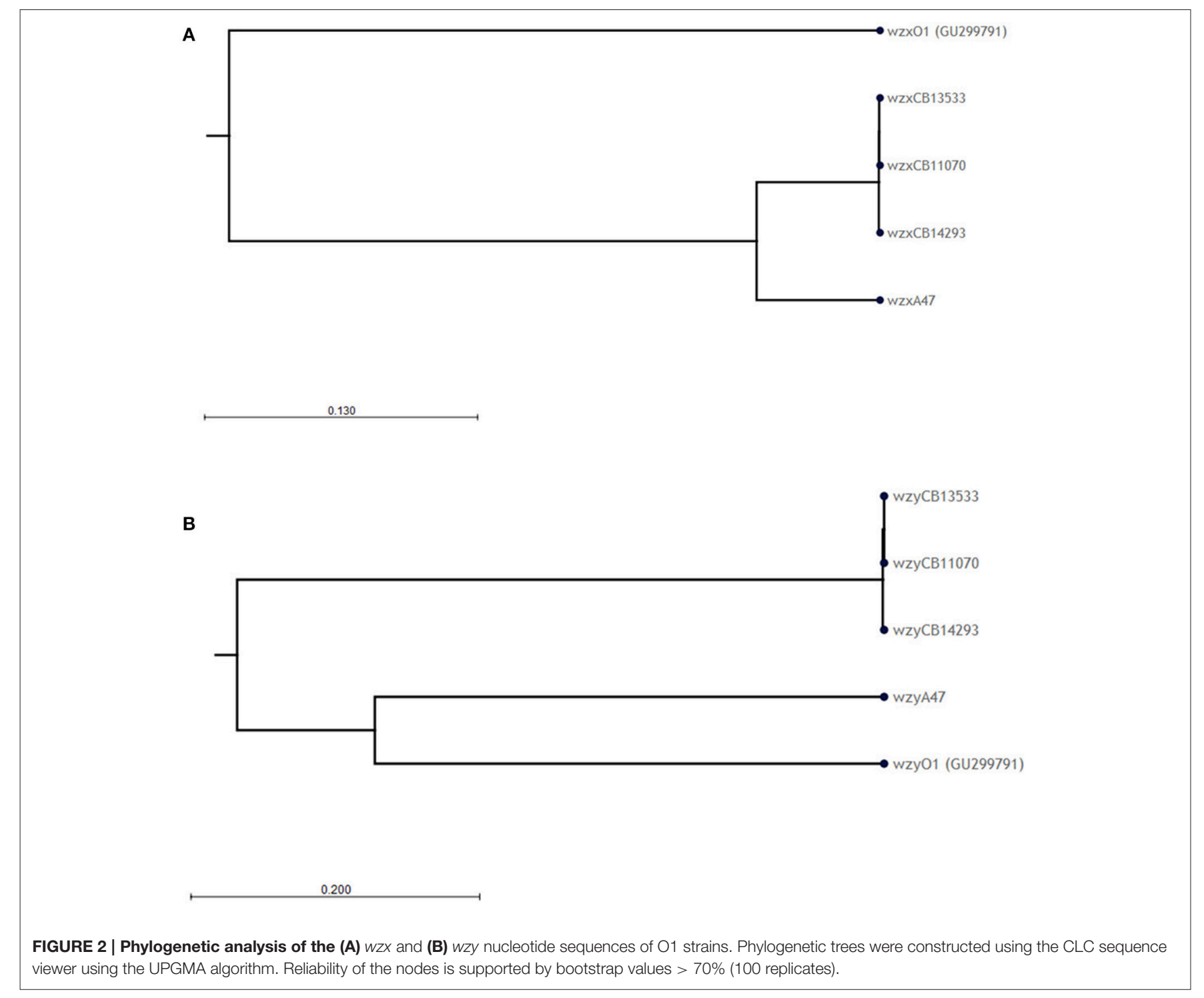

except for wzxO2 qPCR test which reacted with reference strains for serogroups $\mathrm{O} 2$ and $\mathrm{O} 50$. Additionally, when tested against the panel of 153 strains (Table 5), including 115 strains of serogroups other than $\mathrm{O} 2$, none of the strains belonging to $\mathrm{O}$-groups other than $\mathrm{O} 2$ reacted with the $\mathrm{wzxO} 2$, the wzxO2-2 or with the wzxO2-3 qPCR assays. The wzxO2 qPCR assay reacted only with ExPEC and STEC strains of serotype O2:H1 $(n=2), \mathrm{O} 2: \mathrm{K} 5: \mathrm{H} 1$ $(n=1), \mathrm{O} 2: \mathrm{K} 1: \mathrm{H} 1(n=2), \mathrm{O} 2: \mathrm{K} 5: \mathrm{H} 4(n=2), \mathrm{O} 2: \mathrm{K} 1: \mathrm{H} 4(n=3)$, O2:K1:H5 ( $n=3), \mathrm{O} 2: \mathrm{K} 1: \mathrm{H} 6(n=4), \mathrm{O} 2: \mathrm{K} 1: \mathrm{H} 7(n=1), \mathrm{O} 2: \mathrm{H} 25$ $(n=4), \mathrm{O} 2: \mathrm{H} 27(n=3), \mathrm{O} 2: \mathrm{H} 32(n=1)$ and $\mathrm{O} 2: \mathrm{K} 1: \mathrm{H} 48(n=1)$. The wzxO2-2 qPCR assay reacted with EPEC and STEC strains of serotype $\mathrm{O} 2: \mathrm{H} 34(n=1), \mathrm{O} 2: \mathrm{H} 49(n=3)$, and O2:H29 $(n=2)$. The wzxO2-3 qPCR reacted only with EPEC strains of serotype $\mathrm{O} 2: \mathrm{H} 8(n=1)$ and $\mathrm{O} 2: \mathrm{H} 40(n=4)$.

The specificity of the neuB qPCR for indicating strains producing the $\mathrm{K} 1$ antigen was tested on the serotype reference strains O1-O186 which have been analyzed for their capsular antigens (Orskov and Orskov, 1984; Orskov et al., 1984; Scheutz et al., 2004; Joensen et al., 2015). None of the strains except those carrying the K1 antigen (U5-41, U941, Bi7509-41, F11119-41, and H61) reacted with the neuB qPCR. The neuB qPCR was further evaluated on E. coli $\mathrm{K} 1$ strains belonging to different $\mathrm{O}$-groups which were from clinical samples and from stool of healthy infants (Wullenweber et al., 1993). In the group of E. coli O1 strains, the $\mathrm{K} 1$ antigen gene was only detected in O1:K1:H7 strains isolated from humans and poultry (Table 3). In the group of $E$. coli $\mathrm{O} 2$ strains, the $\mathrm{K} 1$ antigen gene was detected in $\mathrm{O} 2: \mathrm{K} 1: \mathrm{H} 1, \mathrm{O} 2: \mathrm{K} 1: \mathrm{H} 4, \mathrm{O} 2: \mathrm{K} 1: \mathrm{H} 5, \mathrm{O} 2: \mathrm{K} 1: \mathrm{H} 6$, $\mathrm{O} 2: \mathrm{K} 1: \mathrm{H} 7, \mathrm{O} 2: \mathrm{K} 1: \mathrm{H} 9$, and $\mathrm{O} 2: \mathrm{K} 1: \mathrm{H} 48$, from humans and animals (Table 4). Among the other strains of serogroups other than $\mathrm{O} 1$ and $\mathrm{O} 2$, only four ExPEC strains isolated from humans (ONT:K1:H4, O134:K1:HNT, O166:K1:H7, and O13/O135/O129:K1:H4) reacted with the K1 qPCR assay 
TABLE 4 | Investigation of E. coli $\mathrm{O} 2$ strains by qPCR with $\mathrm{O} 2$ and $\mathrm{K} 1$ specific assays.

\begin{tabular}{|c|c|c|c|c|c|c|c|c|}
\hline Serotype & Source, origin & References & Stx & Nos of strains & wzxO2 & wzxO2-2 & wzxO2-3 & neuBK1 \\
\hline $\mathrm{O} 2: \mathrm{K} 1: \mathrm{H} 6$ & Infant feces, Germany & Wullenweber et al., 1993; Bettelheim et al., 2003 & - & 1 & + & - & - & + \\
\hline $\mathrm{O} 2: \mathrm{K} 1: \mathrm{H} 7$ & Infant feces, Germany & Wullenweber et al., 1993; Bettelheim et al., 2003 & - & 1 & + & - & - & + \\
\hline O2: H1 & Calf feces, Germany & This work, 2010 & - & 1 & + & - & - & - \\
\hline $\mathrm{O} 2: \mathrm{K} 1: \mathrm{H} 4$ & Infant feces, Germany & Wullenweber et al., 1993; Bettelheim et al., 2003 & - & 1 & + & - & - & + \\
\hline $\mathrm{O} 2: \mathrm{K} 5: \mathrm{H} 4$ & Infant feces, Germany & Wullenweber et al., 1993; Bettelheim et al., 2003 & - & 2 & + & - & - & - \\
\hline $\mathrm{O} 2: \mathrm{H} 25$ & See footnote a & See footnote a & + & 3 & + & - & - & - \\
\hline O2:H32 & Wild boar, Germany & This work, 2011 & stx2 & 1 & + & - & - & - \\
\hline $\mathrm{O} 2: \mathrm{H} 27$ & Cattle feces, Germany & This work, 2011 & stx2 & 2 & + & - & - & - \\
\hline $\mathrm{O} 2: \mathrm{K} 2: \mathrm{H} 1$ & Infant feces, Germany & Wullenweber et al., 1993; Bettelheim et al., 2003 & - & 1 & + & - & - & - \\
\hline $\mathrm{O} 2: \mathrm{H} 40$ & See footnote b & See footnote b & - & 3 & - & - & + & - \\
\hline $\mathrm{O} 2: \mathrm{H} 34$ & Cat feces, Brazil & Morato et al., 2009 & - & 1 & - & + & - & - \\
\hline $\mathrm{O} 2: \mathrm{H} 49$ & Pig feces, Switzerland & Fröhlicher et al., 2008 & - & 3 & - & + & - & - \\
\hline O2:H29 & Cattle feces & Martin and Beutin, 2011 & stx2 & 2 & - & + & - & - \\
\hline $\mathrm{O} 2: \mathrm{H} 8$ & Sheep feces, Germany & Krause et al., 2005 & - & 1 & - & - & + & - \\
\hline
\end{tabular}

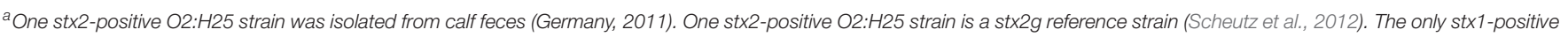
O2:H25 strain was isolated from cattle (Beutin et al., 1993).

${ }^{b} \mathrm{O} 2: H 40$ strains were isolated from pig and sheep feces, (2007) (Fröhlicher et al., 2008) and chicken meat (this work, 2013).

(Table 5). These four strains were previously found K1-positive by latex agglutination.

\section{DISCUSSION}

Escherichia coli strains of serogroups $\mathrm{O} 1$ and $\mathrm{O} 2$ belong to the most frequently isolated E. coli types from humans (Orskov and Orskov, 1992; Olesen et al., 1995; Bettelheim et al., 2003; Ciesielczuk et al., 2016) and also have a broad reservoir in pets and domestic animals (Moulin-Schouleur et al., 2007; Dziva and Stevens, 2008; Ewers et al., 2014). Because of their incidence, clinical importance and type diversity, a reliable identification of $E$. coli $\mathrm{O} 1$ and $\mathrm{O} 2$ serogroups together with the frequently associated $\mathrm{K} 1$ capsule is important for diagnosis and source attribution of $E$. coli infections in humans and animals. Detection of $E$. coli $\mathrm{O} 1$ and $\mathrm{O} 2$ strains by conventional serotyping with $\mathrm{O}$ antigen specific rabbit antisera is hampered by cross reactions that were found between E. coli $\mathrm{O} 1$ and $\mathrm{O} 2$ and also with many other E. coli O-serogroups (Orskov and Orskov, 1984; Edwards and Ewing, 1986). Detection of the K1 capsule is made either by serotyping or by lysotyping with K1-specific bacteriophages (Gross et al., 1977; Orskov et al., 1977). Both methods are costly and rather difficult to introduce in routine clinical diagnosis and would be advantageously replaced by molecular methods.

The LPS of E. coli O1 strains exhibit some structural variations which cross-react in conventional serotyping assays. The common epitope between the $\mathrm{O} 1$ variants contains an $\mathrm{N}$ acetylmannosamine residue branched on an $L$-rhamnose residue (Gupta et al., 1992). Moreover, E. coli O1 antisera were reported to show multiple cross-reactions with other O-serogroups. With the $\mathrm{O} 1$ antiserum used here for serotyping, serological crossreactions with reference strains for $\mathrm{O}$-serogroups $\mathrm{O} 2, \mathrm{O} 10, \mathrm{O} 50$, O53, O107, O115, O117, O148, O149, and O154 were observed, corresponding to previously published findings (Orskov and Orskov, 1984; Edwards and Ewing, 1986). All of these O-groups possess the rmlBDAC genes (Iguchi et al., 2015a; DebRoy et al., 2016) involved in the synthesis of $L$-rhamnose residues which must be part of their antigenic epitope and may be the cause of the serological cross-reactions. Similarly, O2 antisera can show crossreactions with serogroups $\mathrm{O} 1, \mathrm{O} 2 / \mathrm{O} 50, \mathrm{O} 53, \mathrm{O} 74$, and $\mathrm{O} 117$ (Orskov et al., 1977). The O2 antiserum used here agglutinated strains belonging to these O-groups as well as O184 which was not in the serotyping scheme published by Orskov in 1977 (Orskov et al., 1977). The molecular basis of these serological cross-reactions is not clear as the O-AGC of these serogroups exhibit few common features.

In an effort to build a complete molecular serotyping scheme for $E$. coli we sought to develop qPCR assays for the specific detection of O1, O2 LPS and the K1 capsule. Based on the nucleotide sequence of the wzy gene of the $\mathrm{O} 1$ reference strain G1632 (U5-41) we developed a qPCR assay for specific detection of $\mathrm{O} 1$ strains. While this assay appeared highly specific, as it did not cross react with any other serogroups, several strains identified as $\mathrm{O} 1$ with the seroagglutination failed to react. In the same way, a highly specific qPCR assay developed based on the $w z x$ gene of the $\mathrm{O} 2$ reference strain G1674 failed to react with several strains identified as O2 with the seroagglutination. The qPCR assay developed for specific detection of the neuB gene of K1 strains proved $100 \%$ sensitive and $100 \%$ specific.

Analysis of the O-AGC of non-reacting $\mathrm{O} 1$ and $\mathrm{O} 2$ strains revealed significant nucleotide sequence divergences. The O-AGC in the non-reacting O1 strains CB11070, CB13533, and CB14293 appears to be a variant of the one in O1A reference strain G1632. The O1A polysaccharide contains five sugar residues: 3 L-rhamnose residues, an $N$-acetylglucosamine residue and an $N$-Acetyl- $D$-mannosamine residue. The 


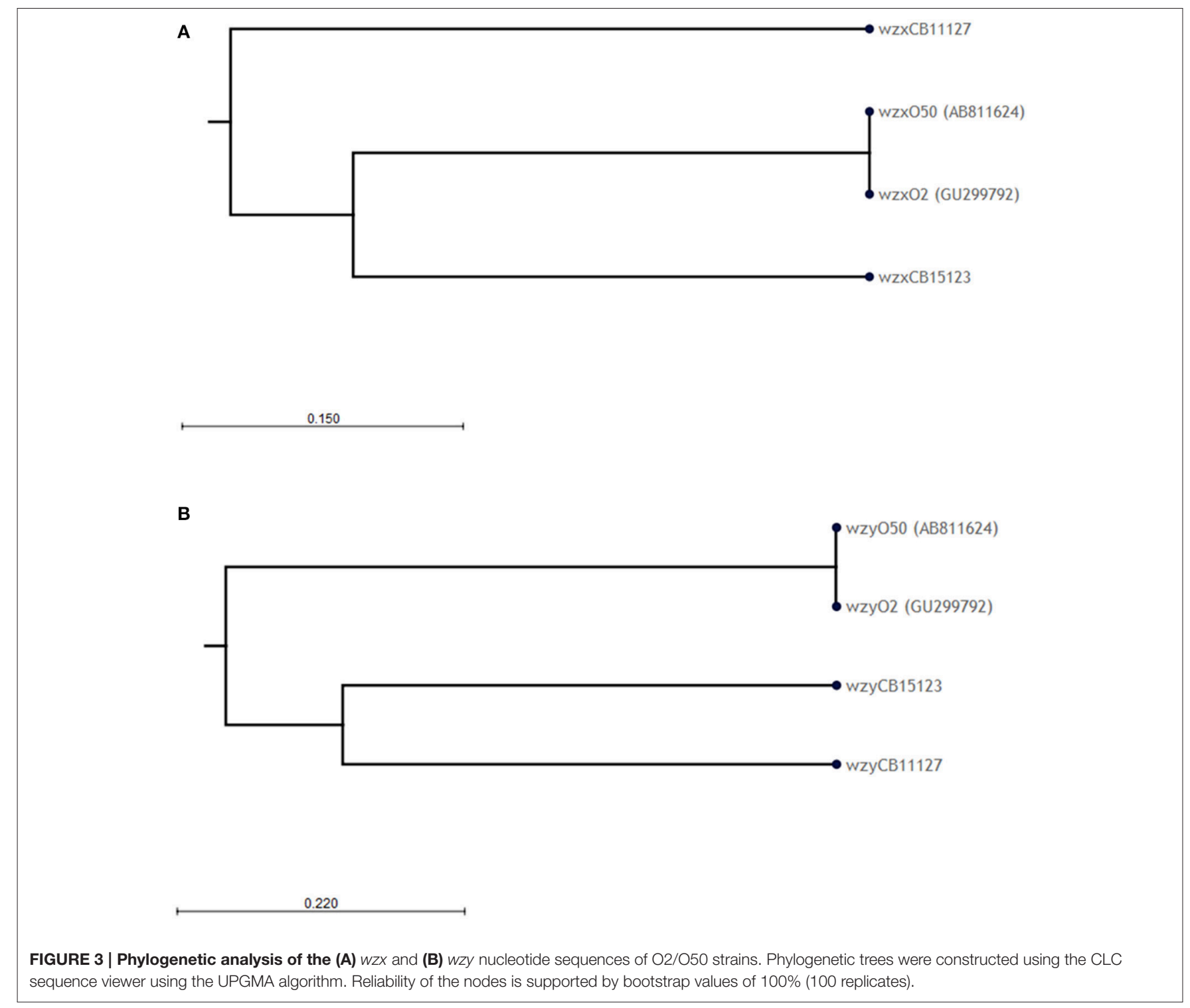

O1B/O1C variants contain two $L$-rhamnose residues, an $N$-acetylglucosamine residue, an $N$-Acetyl- $D$-mannosamine residue and a $D$-Galactose residue (Moll et al., 1986; Gupta et al., 1992). Strains CB11070, CB13533, and CB14293 all apparently conserved the ability to synthesize $L$-rhamnose residues, $N$-acetylglucosamine residues and $N$-Acetyl- $D$ mannosamine residues. The presence of a $D$-Galactose residue in these strains cannot be inferred from the O-AGC sequence. Presence of other residues whose biosynthesis genes are located outside of the O-AGC cannot be ruled out. Indeed, genes involved in the biosynthesis of the nucleotide precursors of common sugars are usually located outside O-antigen gene clusters (Stenutz et al., 2006). Additional LPS-modifying enzymes can also be found elsewhere in the chromosome (Wang et al., 2002), especially in bacteriophages (Allison and Verma, 2000; Perry et al., 2009). The differences in genetic sequence of the whole cluster suggest a clonal divergence and parallel evolution of $\mathrm{O} 1 \mathrm{~A}$ and $\mathrm{O} 1$ nonA strains. The genetic structure of the O-AGC of strain A47 appears to be a mosaic structure containing three modules. The first module (in the transcriptional orientation), containing seven genes including $w z x$, derives from the same $\mathrm{O} 1$ variant. The second module, containing four genes including $w z y$, is related to the $\mathrm{O} 10$ $\mathrm{O}-\mathrm{AGC}$. The third module contains a single gene derived from the O2-OAGC. This mosaic structure suggests a recombination between the O-AGC of strains of serogroups O1, O10 and O2. Generation of new serogroup variants through recombination of parts of the O-AGC has already been reported for serogroup O9 (Sugiyama et al., 1998) and could be used to generate new epitopes and evade detection by the immune system of the host.

The O-AGC found in O2 strains CB11127 and CB15123 constitute two new O2-like serogroups. The genetic structure of the O-AGCs in strains CB11127 and CB15123 are different from 
TABLE 5 | E. coli strains tested by real-time PCR.

\begin{tabular}{|c|c|}
\hline Group ( $n^{\circ}$ of strains) & Serotypes ( $n^{\circ}$ of strains) \\
\hline $01(n=23)$ & $\mathrm{O} 1: \mathrm{K} 1: \mathrm{H} 7(n=17) ; \mathrm{O} 1:[\mathrm{H} 21] ; \mathrm{O} 1: \mathrm{H} 20(n=3) ; \mathrm{O} 1: \mathrm{H} 33 ; \mathrm{O} 1: \mathrm{H} 12$ \\
\hline $\mathrm{O} 2(n=38)$ & $\begin{array}{l}\mathrm{O} 2: \mathrm{H} 32 ; \mathrm{O} 2: \mathrm{H} 25(n=4) ; \mathrm{O} 2: \mathrm{K} 5: \mathrm{H} 4(n=2) ; \mathrm{O} 2: \mathrm{K} 1: \mathrm{H} 4 ; \mathrm{O} 2: \mathrm{K} 2: \mathrm{H} 1 ; \mathrm{O} 2: \mathrm{H} 1 ; \mathrm{O} 2: \mathrm{K} 5: \mathrm{H} 1 ; \mathrm{O} 2: \mathrm{H} 27(n=3) ; \mathrm{O} 2: \mathrm{K} 1: \mathrm{H} 6 ; \mathrm{O} 2: \mathrm{K} 1: \mathrm{H} 7 ; \mathrm{O} 2: \mathrm{K} 1: \mathrm{H} 4 \\
(n=2) ; \mathrm{O} 2: \mathrm{K} 1: \mathrm{H} 1(n=2) ; \mathrm{O} 2: \mathrm{K} 1: \mathrm{H} 5(n=3) ; \mathrm{O} 2: \mathrm{K} 1: \mathrm{H} 6(n=3) ; \mathrm{O} 2: \mathrm{K} 1: \mathrm{H} 48 ; \mathrm{O} 2: \mathrm{H} 34 ; \mathrm{O} 2: \mathrm{H} 49(n=3), \mathrm{O} 2: \mathrm{H} 29(n=2) ; \mathrm{O} 2: \mathrm{H} 8 ; \mathrm{O} 2: \mathrm{H} 40 \\
(n=4)\end{array}$ \\
\hline $\mathrm{K} 1$ (non O1, non O2) $(n=4)$ & ONT:K1:H4; [O134]:K1:HNT; [O166]:K1:H7; [O13/O135/O129]:K1:H4 \\
\hline Other $(n=88)$ & 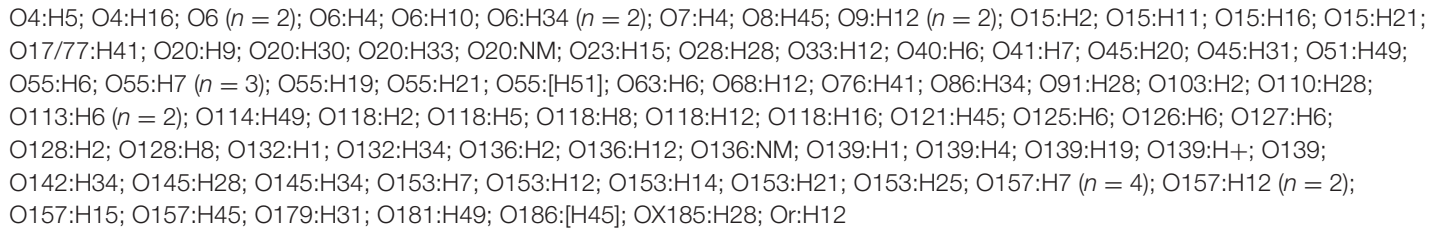 \\
\hline
\end{tabular}

For each serotype, $n=1$ unless otherwise stated. Serotypes between brackets were determined by sequencing.

that of the O2 reference strain G1674 suggesting different LPS structures. The $\mathrm{O} 2$ polysaccharide contains three L-rhamnose residues, an $\mathrm{N}$-acetylglucosamine residue, and an $\mathrm{N}$-acetylD-galactosamine (Jansson et al., 1987). Strain CB11127 most likely lacks the $L$-rhamnose residues as the absence of the rmlC and $r m l D$ genes prevents full transformation of glucose1-phosphate into dTDP- $L$-Rhamnose. Instead, presence of the man $B$ and man $C$ genes suggests the presence of residue(s) derived from GDP-D-Mannose. Presence of $r m l A, r m l B, f d t A$, $f d t B$, and $f d t C$ suggest that the $\mathrm{N}$-acetyl-D-galactosamine residue is conserved. Strain CB15123 conserved both the ability to synthesize $L$-rhamnose residues and $\mathrm{N}$-acetyl- $D$-galactosamine residues and also acquired the GDP- $D$-Mannose pathway. Once again, presence of other residues whose biosynthesis genes are located outside of the O-AGC cannot be ruled out.

Based on the nucleotide sequence of the new O1-variant and the two O2-like serogroups, specific qPCR assays were developed, which proved to be $100 \%$ sensitive and $100 \%$ specific, and able to clearly distinguish the different genetic variants identified within each serogroup.

Overall, the various qPCR assays designed in this study can be used for detection and rapid identification of the different types of E. coli strains of serogroups O1 and O2. They provide a significantly improved alternative to classical O-serotyping by their high specificity and sensitivity to detect virtually all types of $\mathrm{O} 1$ and $\mathrm{O} 2$ strains and their respective associated variants. They are therefore potentially useful for direct identification of clinically important $\mathrm{O} 1$ and $\mathrm{O} 2$ strains in food and clinical specimens. These different qPCR assays can thus serve as tools for epidemiological investigations and source attribution of human infections. Molecular typing by use of specific qPCRs provides a more specific detection of clinically important $\mathrm{O} 1$ and $\mathrm{O} 2 \mathrm{ExPEC}$ strains. Ambiguous results obtained by serotyping such as crossreactions with other $E$. coli $\mathrm{O}$-groups and agglutination reactions with O-rough strains are avoided. Moreover, the qPCR approach described in this study provides a better discrimination between $\mathrm{O} 1$ and O2 ExPEC and non-ExPEC strains. In combination with the detection of the neuB gene (K1 capsule), life-threatening O1 and $\mathrm{O} 2 \mathrm{ExPEC}$ infections in risk groups such as newborn infants can be more rapidly identified. Asymptomatic carriers, animals and food contaminated with $\mathrm{O} 1$ and $\mathrm{O} 2$ ExPEC strains can be more easily identified and the spread of pathogens to human risk groups (new born-infants, elderly, and intensive-care patients) can thus be prevented. The qPCR detection of ExPEC O1 and O2 strains is a reliable and easy approach to elucidate the significance of zoonotic and food-borne infection of humans with ExPEC O1 and $\mathrm{O} 2$ strains in epidemiological investigations.

\section{AUTHOR CONTRIBUTIONS}

Conceived and designed the experiments: LB, SD, and PF. Performed the experiments: SD, LB, PM, AF, and SB. Analyzed the data: SD, LB, PM, AF, SB, and PF. Contributed reagents/materials/analysis tools: $\mathrm{SD}, \mathrm{LB}, \mathrm{PM}, \mathrm{SB}$, and PF. Wrote the paper: $\mathrm{SD}, \mathrm{LB}$, and $\mathrm{PF}$. Critical revision of the paper for important intellectual content: SD, LB, PM, AF, SB, and PF.

\section{ACKNOWLEDGMENTS}

We thank Yannick Marie from the iGenSeq Genotyping and Sequencing Core facility at the ICM Brain and Spine Institute for generating the library and sequencing the O-AGC of strain U18-41 (O50).

\section{SUPPLEMENTARY MATERIAL}

The Supplementary Material for this article can be found online at: http://journal.frontiersin.org/article/10.3389/fcimb. 2017.00030/full\#supplementary-material 


\section{REFERENCES}

Achtman, M., Heuzenroeder, M., Kusecek, B., Ochman, H., Caugant, D., Selander, R. K., et al. (1986). Clonal analysis of Escherichia coli O2:K1 isolated from diseased humans and animals. Infect. Immun. 51, 268-276.

Achtman, M., Mercer, A., Kusecek, B., Pohl, A., Heuzenroeder, M., Aaronson, W., et al. (1983). Six widespread bacterial clones among Escherichia coli K1 isolates. Infect. Immun. 39, 315-335.

Allison, G. E., and Verma, N. K. (2000). Serotype-converting bacteriophages and O-antigen modification in Shigella flexneri. Trends Microbiol. 8, 17-23. doi: 10.1016/S0966-842X(99)01646-7

Alonso, M. Z., Sanz, M. E., Irino, K., Krüger, A., Lucchesi, P. M., and Padola, N. L. (2016). Isolation of atypical enteropathogenic Escherichia coli from chicken and chicken-derived products. Br. Poult. Sci. 57, 161-164. doi: 10.1080/00071668.2015.1135502

Bettelheim, K. A., Beutin, L., Gleier, K., Pearce, J. L., Luke, R. K., and Zimmermann, S. (2003). Serotypes of Escherichia coli isolated from healthy infants in Berlin, Germany and Melbourne, Australia. Comp. Immunol. Microbiol. Infect. Dis. 26, 55-63. doi: 10.1016/S0147-9571(02)00015-2

Beutin, L., Delannoy, S., and Fach, P. (2016). Genetic analysis and detection of $f l i C_{\mathrm{H} 1}$ and $f l i C_{\mathrm{H} 12}$ genes coding for serologically closely related flagellar antigens in human and animal pathogenic Escherichia coli. Front. Microbiol. 7:135. doi: $10.3389 /$ fmicb. 2016.00135

Beutin, L., Geier, D., Steinrück, H., Zimmermann, S., and Scheutz, F. (1993). Prevalence and some properties of verotoxin (Shiga-like toxin)-producing Escherichia coli in seven different species of healthy domestic animals. J. Clin. Microbiol. 31, 2483-2488.

Beutin, L., Krause, G., Zimmermann, S., Kaulfuss, S., and Gleier, K. (2004). Characterization of Shiga toxin-producing Escherichia coli strains isolated from human patients in Germany over a 3-year period. J. Clin. Microbiol. 42, 1099-1108. doi: 10.1128/JCM.42.3.1099-1108.2004

Beutin, L., Miko, A., Krause, G., Pries, K., Haby, S., Steege, K., et al. (2007). Identification of human-pathogenic strains of Shiga toxin-producing Escherichia coli from food by a combination of serotyping and molecular typing of Shiga toxin genes. Appl. Environ. Microbiol. 73, 4769-4775. doi: 10.1128/AEM.00873-07

Bidet, P., Mahjoub-Messai, F., Blanco, J., Blanco, J., Dehem, M., Aujard, Y., et al. (2007). Combined multilocus sequence typing and $O$ serogrouping distinguishes Escherichia coli subtypes associated with infant urosepsis and/or meningitis. J. Infect. Dis. 196, 297-303. doi: 10.1086/518897

Blanco, J. E., Blanco, M., Alonso, M. P., Mora, A., Dahbi, G., Coira, M. A., et al. (2004). Serotypes, virulence genes, and intimin types of Shiga toxin (verotoxin)-producing Escherichia coli isolates from human patients: prevalence in Lugo, Spain, from 1992 through 1999. J. Clin. Microbiol. 42, 311-319. doi: 10.1128/JCM.42.1.311-319.2004

Bugarel, M., Beutin, L., and Fach, P. (2010). Low-density macroarray targeting non-locus of enterocyte effacement effectors (nle genes) and major virulence factors of Shiga toxin-producing Escherichia coli (STEC): a new approach for molecular risk assessment of STEC isolates. Appl. Environ. Microbiol. 76, 203-211. doi: 10.1128/AEM.01921-09

Chen, Y., Chen, X., Zheng, S., Yu, F., Kong, H., Yang, Q., et al. (2014). Serotypes, genotypes and antimicrobial resistance patterns of human diarrhoeagenic Escherichia coli isolates circulating in southeastern China. Clin. Microbiol. Infect. 20, 52-58. doi: 10.1111/1469-0691.12188

Ciesielczuk, H., Jenkins, C., Chattaway, M., Doumith, M., Hope, R., Woodford, N., et al. (2016). Trends in ExPEC serogroups in the UK and their significance. Eur. J. Clin. Microbiol. Infect. Dis. 35, 1661-1666. doi: 10.1007/s10096-016-2707-8

Clermont, O., Johnson, J. R., Menard, M., and Denamur, E. (2007). Determination of Escherichia coli $\mathrm{O}$ types by allele-specific polymerase chain reaction: application to the $\mathrm{O}$ types involved in human septicemia. Diagn. Microbiol. Infect. Dis. 57, 129-136. doi: 10.1016/j.diagmicrobio.2006.08.007

Coimbra, R. S., Grimont, F., Lenormand, P., Burguière, P., Beutin, L., and Grimont, P. A. (2000). Identification of Escherichia coli O-serogroups by restriction of the amplified O-antigen gene cluster (rfb-RFLP). Res. Microbiol. 151, 639-654. doi: 10.1016/S0923-2508(00)00134-0

Damborg, P., Nielsen, S. S., and Guardabassi, L. (2009). Escherichia coli shedding patterns in humans and dogs: insights into within-household transmission of phylotypes associated with urinary tract infections. Epidemiol. Infect. 137, 1457-1464. doi: 10.1017/S095026880900226X

DebRoy, C., Fratamico, P. M., Yan, X., Baranzoni, G., Liu, Y., Needleman, D. S., et al. (2016). Comparison of O-Antigen gene clusters of all O-Serogroups of Escherichia coli and proposal for adopting a new nomenclature for O-Typing. PLoS ONE 11:e0147434. doi: 10.1371/journal.pone.0147434

Diarra, M. S., Giguere, K., Malouin, F., Lefebvre, B., Bach, S., Delaquis, P., et al. (2009). Genotype, serotype, and antibiotic resistance of sorbitolnegative Escherichia coli isolates from feedlot cattle. J. Food Prot. 72, 28-36. doi: 10.4315/0362-028X-72.1.28

Döpfer, D., Sekse, C., Beutin, L., Solheim, H., Van Der Wal, F. J., De Boer, A., et al. (2010). Pathogenic potential and horizontal gene transfer in ovine gastrointestinal Escherichia coli. J. Appl. Microbiol. 108, 1552-1562. doi: 10.1111/j.1365-2672.2009.04575.x

Dziva, F., and Stevens, M. P. (2008). Colibacillosis in poultry: unravelling the molecular basis of virulence of avian pathogenic Escherichia coli in their natural hosts. Avian Pathol. 37, 355-366. doi: 10.1080/03079450802216652

Edwards, P. R., and Ewing, W. H. (1986). Edwards and Ewing's Identification of Enterobacteriaceae. New York, NY: Elsevier Science Publishing Co. Inc.

Ewers, C., Bethe, A., Stamm, I., Grobbel, M., Kopp, P. A., Guerra, B., et al. (2014). CTX-M-15-D-ST648 Escherichia coli from companion animals and horses: another pandemic clone combining multiresistance and extraintestinal virulence? J. Antimicrob. Chemother. 69, 1224-1230. doi: 10.1093/jac/dkt516

Fratamico, P. M., Debroy, C., Liu, Y., Needleman, D. S., Baranzoni, G. M., and Feng, P. (2016). Advances in molecular serotyping and subtyping of Escherichia coli. Front. Microbiol. 7:644. doi: 10.3389/fmicb.2016.00644

Fröhlicher, E., Krause, G., Zweifel, C., Beutin, L., and Stephan, R. (2008). Characterization of attaching and effacing Escherichia coli (AEEC) isolated from pigs and sheep. BMC Microbiol. 8:144. doi: 10.1186/1471-2180-8-144

Geser, N., Stephan, R., Korczak, B. M., Beutin, L., and Hachler, H. (2012). Molecular identification of extended-spectrum- $\beta$-lactamase genes from Enterobacteriaceae isolated from healthy human carriers in Switzerland. Antimicrob. Agents Chemother. 56, 1609-1612. doi: 10.1128/AAC.05 539-11

Gross, R. J., Cheasty, T., and Rowe, B. (1977). Isolation of bacteriophages specific for the K1 polysaccharide antigen of Escherichia coli. J. Clin. Microbiol. 6, $548-550$.

Guo, H., Feng, L., Tao, J., Zhang, C., and Wang, L. (2004). Identification of Escherichia coli O172 O-antigen gene cluster and development of a serogroup-specific PCR assay. J. Appl. Microbiol. 97, 181-190. doi: 10.1111/j.1365-2672.2004.02305.x

Guo, S., Wakeham, D., Brouwers, H. J., Cobbold, R. N., Abraham, S., Mollinger, J. L., et al. (2015). Human-associated fluoroquinolone-resistant Escherichia coli clonal lineages, including ST354, isolated from canine feces and extraintestinal infections in Australia. Microbes Infect. 17, 266-274. doi: 10.1016/j.micinf.2014.12.016

Gupta, D. S., Shashkov, A. S., Jann, B., and Jann, K. (1992). Structures of the $\mathrm{O} 1 \mathrm{~B}$ and O1C lipopolysaccharide antigens of Escherichia coli. J. Bacteriol. 174, 7963-7970. doi: 10.1128/jb.174.24.7963-7970.1992

Houdouin, V., Bonacorsi, S., Bidet, P., Blanco, J., De La Rocque, F., Cohen, R., et al. (2008). Association between mortality of Escherichia coli meningitis in young infants and non-virulent clonal groups of strains. Clin. Microbiol. Infect. 14, 685-690. doi: 10.1111/j.1469-0691.2008.02019.x

Hussein, H. S., and Bollinger, L. M. (2005). Prevalence of Shiga toxinproducing Escherichia coli in beef cattle. J. Food Prot. 68, 2224-2241. doi: 10.4315/0362-028X-68.10.2224

Hutchinson, J. P., Cheney, T. E., Smith, R. P., Lynch, K., and Pritchard, G. C. (2011). Verocytotoxin-producing and attaching and effacing activity of Escherichia coli isolated from diseased farm livestock. Vet. Rec. 168:536. doi: 10.1136/vr.d915

Iguchi, A., Iyoda, S., Kikuchi, T., Ogura, Y., Katsura, K., Ohnishi, M., et al. (2015a). A complete view of the genetic diversity of the Escherichia coli O-antigen biosynthesis gene cluster. DNA Res. 22, 101-107. doi: 10.1093/dnares/dsu043

Iguchi, A., Iyoda, S., Seto, K., Morita-Ishihara, T., Scheutz, F., Ohnishi, M., et al. (2015b). Escherichia coli O-Genotyping PCR: a comprehensive and practical platform for molecular O Serogrouping. J. Clin. Microbiol. 53, 2427-2432. doi: 10.1128/JCM.00321-15 
Jakobsen, L., Spangholm, D. J., Pedersen, K., Jensen, L. B., Emborg, H. D., Agersø, Y., et al. (2010). Broiler chickens, broiler chicken meat, pigs and pork as sources of ExPEC related virulence genes and resistance in Escherichia coli isolates from community-dwelling humans and UTI patients. Int. J. Food Microbiol. 142, 264-272. doi: 10.1016/j.ijfoodmicro.2010.06.025

Jansson, P. E., Lennholm, H., Lindberg, B., Lindquist, U., and Svenson, S. B. (1987). Structural studies of the O-specific side-chains of the Escherichia coli O2 lipopolysaccharide. Carbohydr. Res. 161, 273-279. doi: 10.1016/S0008-6215(00)90084-3

Joensen, K. G., Tetzschner, A. M., Iguchi, A., Aarestrup, F. M., and Scheutz, F. (2015). Rapid and easy in silico serotyping of Escherichia coli isolates by use of whole-genome sequencing data. J. Clin. Microbiol. 53, 2410-2426. doi: 10.1128/JCM.00008-15

Johnson, J. R., Owens, K. L., Clabots, C. R., Weissman, S. J., and Cannon, S. B. (2006). Phylogenetic relationships among clonal groups of extraintestinal pathogenic Escherichia coli as assessed by multi-locus sequence analysis. Microbes Infect. 8, 1702-1713. doi: 10.1016/j.micinf.2006.02.007

Johnson, T. J., Kariyawasam, S., Wannemuehler, Y., Mangiamele, P., Johnson, S. J., Doetkott, C., et al. (2007). The genome sequence of avian pathogenic Escherichia coli strain O1:K1:H7 shares strong similarities with human extraintestinal pathogenic E. coli genomes. J. Bacteriol. 189, 3228-3236. doi: 10.1128/JB.01726-06

Johnson, T. J., Logue, C. M., Johnson, J. R., Kuskowski, M. A., Sherwood, J. S., Barnes, H. J., et al. (2012a). Associations between multidrug resistance, plasmid content, and virulence potential among extraintestinal pathogenic and commensal Escherichia coli from humans and poultry. Foodborne Pathog. Dis. 9, 37-46. doi: 10.1089/fpd.2011.0961

Johnson, T. J., Wannemuehler, Y., Kariyawasam, S., Johnson, J. R., Logue, C. M., and Nolan, L. K. (2012b). Prevalence of avian-pathogenic Escherichia coli strain $\mathrm{O} 1$ genomic islands among extraintestinal and commensal $E$. coli isolates. J. Bacteriol. 194, 2846-2853. doi: 10.1128/JB.06375-11

Kobayashi, Y., Maeyama, K., Shiki, Y., Tsukamoto, T., Nagai, T., Peina, Y., et al. (1993). [Sporadic case of hemolytic uremic syndrome associated with verotoxin producing Escherichia coli O2:K1:H7]. Kansenshogaku Zasshi 67, 116-121. doi: 10.11150/kansenshogakuzasshi1970.67.116

Krause, G., Zimmermann, S., and Beutin, L. (2005). Investigation of domestic animals and pets as a reservoir for intimin- (eae) gene positive Escherichia coli types. Vet. Microbiol. 106, 87-95. doi: 10.1016/j.vetmic.2004.11.012

Li, D., Liu, B., Chen, M., Guo, D., Guo, X., Liu, F., et al. (2010). A multiplex PCR method to detect 14 Escherichia coli serogroups associated with urinary tract infections. J. Microbiol. Methods 82, 71-77. doi: 10.1016/j.mimet.2010.04.008

Lu, S., Zhang, X., Zhu, Y., Kim, K. S., Yang, J., and Jin, Q. (2011). Complete genome sequence of the neonatal-meningitis-associated Escherichia coli strain CE10. J. Bacteriol. 193:7005. doi: 10.1128/jb.06284-11

Manges, A. R., and Johnson, J. R. (2015). Reservoirs of extraintestinal pathogenic Escherichia coli. Microbiol. Spectr. 3. doi: 10.1128/microbiolspec.UTI-0006-2012

Martin, A., and Beutin, L. (2011). Characteristics of Shiga toxin-producing Escherichia coli from meat and milk products of different origins and association with food producing animals as main contamination sources. Int. J. Food Microbiol. 146, 99-104. doi: 10.1016/j.ijfoodmicro.2011. 01.041

Mekata, H., Iguchi, A., Kawano, K., Kirino, Y., Kobayashi, I., and Misawa, N. (2014). Identification of O serotypes, genotypes, and virulotypes of Shiga toxinproducing Escherichia coli isolates, including non-O157 from beef cattle in Japan. J. Food Prot. 77, 1269-1274. doi: 10.4315/0362-028X.JFP-13-506

Mitchell, A., Chang, H. Y., Daugherty, L., Fraser, M., Hunter, S., Lopez, R., et al. (2015). The InterPro protein families database: the classification resource after 15 years. Nucleic Acids Res. 43, D213-221. doi: 10.1093/nar/gku1243

Moll, A., Kusecek, B., Pluschke, G., Morelli, G., Kamke, M., Jann, B., et al. (1986). A reexamination of the O1 lipopolysaccharide antigen group of Escherichia coli. Infect. Immun. 53, 257-263.

Mora, A., López, C., Dabhi, G., Blanco, M., Blanco, J. E., Alonso, M. P., et al. (2009). Extraintestinal pathogenic Escherichia coli O1:K1:H7/NM from human and avian origin: detection of clonal groups B2 ST95 and D ST59 with different host distribution. BMC Microbiol. 9:132. doi: 10.1186/1471-2180-9-132

Morato, E. P., Leomil, L., Beutin, L., Krause, G., Moura, R. A., and Pestana De Castro, A. F. (2009). Domestic cats constitute a natural reservoir of human enteropathogenic Escherichia coli types. Zoonoses Public Health 56, 229-237. doi: 10.1111/j.1863-2378.2008.01190.x

Moreno, E., Johnson, J. R., Pérez, T., Prats, G., Kuskowski, M. A., and Andreu, A. (2009). Structure and urovirulence characteristics of the fecal Escherichia coli population among healthy women. Microbes Infect. 11, 274-280. doi: 10.1016/j.micinf.2008.12.002

Moulin-Schouleur, M., Répérant, M., Laurent, S., Brée, A., Mignon-Grasteau, S., Germon, P., et al. (2007). Extraintestinal pathogenic Escherichia coli strains of avian and human origin: link between phylogenetic relationships and common virulence patterns. J. Clin. Microbiol. 45, 3366-3376. doi: 10.1128/JCM.00037-07

Nandanwar, N., Janssen, T., Kuhl, M., Ahmed, N., Ewers, C., and Wieler, L. H. (2014). Extraintestinal pathogenic Escherichia coli (ExPEC) of human and avian origin belonging to sequence type complex 95 (STC95) portray indistinguishable virulence features. Int. J. Med. Microbiol. 304, 835-842. doi: 10.1016/j.ijmm.2014.06.009

Olesen, B., Kolmos, H. J., Orskov, F., and Orskov, I. (1995). A comparative study of nosocomial and community-acquired strains of Escherichia coli causing bacteraemia in a Danish University Hospital. J. Hosp. Infect. 31, 295-304. doi: 10.1016/0195-6701(95)90208-2

Orskov, F. (1978). Virulence factors of the bacterial cell surface. J. Infect. Dis. 137, 630-633. doi: 10.1093/infdis/137.5.630

Orskov, F., and Orskov, I. (1984). "Serotyping of Escherichia coli," in Methods in Microbiology, ed T. Bergan (London: Academic Press), 43-113.

Orskov, F., and Orskov, I. (1992). Escherichia coli serotyping and disease in man and animals. Can. J. Microbiol. 38, 699-704. doi: 10.1139/m92-115

Orskov, I., Orskov, F., Jann, B., and Jann, K. (1977). Serology, chemistry, and genetics of $\mathrm{O}$ and $\mathrm{K}$ antigens of Escherichia coli. Bacteriol. Rev. 41, 667-710.

Orskov, I., Orskov, F., and Rowe, B. (1984). Six new E. coli O groups: O165, O166, O167, O168, O169 and O170. Acta Pathol. Microbiol. Immunol. Scand. B 92, 189-193.

Peigne, C., Bidet, P., Mahjoub-Messai, F., Plainvert, C., Barbe, V., Médigue, C., et al. (2009). The plasmid of Escherichia coli strain S88 (O45:K1:H7) that causes neonatal meningitis is closely related to avian pathogenic E. coli plasmids and is associated with high-level bacteremia in a neonatal rat meningitis model. Infect. Immun. 77, 2272-2284. doi: 10.1128/IAI.01333-08

Perelle, S., Dilasser, F., Grout, J., and Fach, P. (2005). Detection of Escherichia coli serogroup $\mathrm{O} 103$ by real-time polymerase chain reaction. J. Appl. Microbiol. 98, 1162-1168. doi: 10.1111/j.1365-2672.2005.02545.x

Perry, L. L., Sanmiguel, P., Minocha, U., Terekhov, A. I., Shroyer, M. L., Farris, L. A., et al. (2009). Sequence analysis of Escherichia coli O157:H7 bacteriophage PhiV10 and identification of a phage-encoded immunity protein that modifies the O157 antigen. FEMS Microbiol. Lett. 292, 182-186. doi: 10.1111/j.1574-6968.2009.01511.x

Reeves, P. R., Hobbs, M., Valvano, M. A., Skurnik, M., Whitfield, C., Coplin, D., et al. (1996). Bacterial polysaccharide synthesis and gene nomenclature. Trends Microbiol. 4, 495-503. doi: 10.1016/S0966-842X(97)82912-5

Riley, L. W. (2014). Pandemic lineages of extraintestinal pathogenic Escherichia coli. Clin. Microbiol. Infect. 20, 380-390. doi: 10.1111/1469-0691.12646

Sánchez, S., García-Sánchez, A., Martinez, R., Blanco, J., Blanco, J. E., Blanco, M., et al. (2009). Detection and characterisation of Shiga toxin-producing Escherichia coli other than Escherichia coli O157:H7 in wild ruminants. Vet. J. 180, 384-388. doi: 10.1016/j.tvjl.2008.01.011

Scheutz, F., Cheasty, T., Woodward, D., and Smith, H. R. (2004). Designation of $\mathrm{O} 174$ and O175 to temporary O groups OX3 and OX7, and six new E. coli $\mathrm{O}$ groups that include Verocytotoxin-producing $E$. coli (VTEC): O176, O177, O178, O179, O180 and O181. APMIS 112, 569-584. doi: 10.1111/j.1600-0463.2004.apm1120903.x

Scheutz, F., Teel, L. D., Beutin, L., Piérard, D., Buvens, G., Karch, H., et al. (2012). Multicenter evaluation of a sequence-based protocol for subtyping Shiga toxins and standardizing Stx nomenclature. J. Clin. Microbiol. 50, 2951-2963. doi: 10.1128/JCM.00860-12

Scott, L., Mcgee, P., Walsh, C., Fanning, S., Sweeney, T., Blanco, J., et al. (2009). Detection of numerous verotoxigenic $E$. coli serotypes, with multiple antibiotic resistance from cattle faeces and soil. Vet. Microbiol. 134, 288-293. doi: $10.1016 /$ j.vetmic. 2008.08 .008

Seemann, T. (2014). Prokka: rapid prokaryotic genome annotation. Bioinformatics 30, 2068-2069. doi: 10.1093/bioinformatics/btu153 
Singer, R. S. (2015). Urinary tract infections attributed to diverse ExPEC strains in food animals: evidence and data gaps. Front. Microbiol. 6:28. doi: $10.3389 /$ fmicb. 2015.00028

Stenutz, R., Weintraub, A., and Widmalm, G. (2006). The structures of Escherichia coli O-polysaccharide antigens. FEMS Microbiol. Rev. 30, 382-403. doi: 10.1111/j.1574-6976.2006. 00016.x

Sugiyama, T., Kido, N., Kato, Y., Koide, N., Yoshida, T., and Yokochi, T. (1998). Generation of Escherichia coli O9a serotype, a subtype of E. coli O9, by transfer of the wb $^{*}$ gene cluster of Klebsiella O3 into E. coli via recombination. J. Bacteriol. 180, 2775-2778.

Vincent, C., Boerlin, P., Daignault, D., Dozois, C. M., Dutil, L., Galanakis, C., et al. (2010). Food reservoir for Escherichia coli causing urinary tract infections. Emerg. Infect. Dis. 16, 88-95. doi: 10.3201/eid1601.0 91118

Wang, L., Huskic, S., Cisterne, A., Rothemund, D., and Reeves, P. R. (2002). The O-antigen gene cluster of Escherichia coli $\mathrm{O} 55: \mathrm{H} 7$ and identification of a new UDP-GlcNAc C4 epimerase gene. J. Bacteriol. 184, 2620-2625. doi: 10.1128/JB.184.10.2620-2625.2002

Wullenweber, M., Beutin, L., Zimmermann, S., and Jonas, C. (1993). Influence of some bacterial and host factors on colonization and invasiveness of Escherichia coli $\mathrm{K} 1$ in neonatal rats. Infect. Immun. 61, 2138-2144.

Conflict of Interest Statement: The authors declare that the research was conducted in the absence of any commercial or financial relationships that could be construed as a potential conflict of interest.

Copyright (C) 2017 Delannoy, Beutin, Mariani-Kurkdjian, Fleiss, Bonacorsi and Fach. This is an open-access article distributed under the terms of the Creative Commons Attribution License (CC BY). The use, distribution or reproduction in other forums is permitted, provided the original author(s) or licensor are credited and that the original publication in this journal is cited, in accordance with accepted academic practice. No use, distribution or reproduction is permitted which does not comply with these terms. 